\title{
PENGEMBANGAN MODEL BLENDED LEARNING INTERAKTIF DENGAN PROSEDUR BORG AND GALL
}

\author{
Hansi Effendi ${ }^{1}$, Yeka Hendriyani ${ }^{2}$ \\ ${ }^{1}$ Jurusan Teknik Elektro, ${ }^{2}$ Jurusan Teknik Elektronika, Fakultas Teknik, \\ Universitas Negeri Padang \\ e-mail : hansieffendi@gmail.com, yecha_053@yahoo.co.id
}

\begin{abstract}
There is no one model of learning that is suitable for all learning situations, therefore a lot of learning models were developed. This article discusses steps of developing a learning model, namely the model of Blended Learning Interactive (BLI) using the procedure Borg $\&$ Gall. Some of the issues discussed in this article is about the model BLI, the nature, characteristics and procedures of research and development, as well as an explanation of each step in the development model of BLI. The result is that by following these steps will produce the model BLI which is valid, effective, and practical.
\end{abstract}

\section{Keywords: Model Development, Blended Learning, Interactive, Borg \& Gall}

\section{PENDAHULUAN}

Perkembangan teknologi informasi dan komunikasi (TIK) telah memberikan pengaruh luar biasa terhadap dunia pendidikan khususnya dalam proses pembelajaran. Menurut Muhammad Surya (2006: 1), dengan perkembangan TIK ini ada 5 pergeseran dalam proses pembelajaran: "(a) dari pelatihan ke penampilan; (b) dari ruang kelas dan jam tertentu ke dimana saja dan kapan saja; (c) dari kertas ke online; (d) dari fasilitas fisik ke fasilitas jaringan; dan (e) dari waktu siklus ke waktu nyata."

Pergeseran ini tentu disebabkan oleh tersedianya berbagai media pendidikan seperti telefon, komputer, internet, email, dan sebagainya. Interaksi antara guru dan peserta didik tidak hanya dilakukan melalui hubungan tatap muka tetapi juga dilakukan dengan menggunakann media-media tersebut.

Istilah lain yang makin populer saat ini adalah e-learning yaitu suatu model pembelajaran dengan menggunakan media teknologi informasi dan komunikasi, khususnya Internet. Huruf "e" pada e-learning merupakan kependekan dari "electronic" (Sohn, 2005: 6). Belum adanya standar yang baku baik dalam hal definisi maupun implementasi $e$ learning menjadikan banyak orang mempunyai konsep yang bermacam-macam.

Salah satu definisi umum dari e-learning diberikan oleh Gilbert \& Jones (2001:68), yaitu: pengiriman materi pembelajaran melalui suatu media elektronik seperti Internet, intranet/extranet, satellite broadcast, audio/video tape, interactive TV, CD-ROM, dan computer-based training (CBT). Definisi yang hampir sama diusulkan juga oleh the Australian National Training Authority-ANTA (2003: 5) dan Urdan and Weggen (2000: 8) yakni meliputi aplikasi dan proses yang menggunakan berbagai media elektronik seperti internet, audio/video tape, interactive TV dan CD-ROM guna mengirimkan materi pembelajaran secara lebih fleksibel.

Urdan and Weggen (2000: 9) menyebutkan bahwa e-learning adalah bagian dari pembelajaran jarak jauh sedangkan pembelajaran online adalah bagian dari e-learning. Di samping itu, istilah e-learning meliputi berbagai aplikasi dan proses seperti computerbased learning, web-based learning, dan virtual classroom; sementara itu pembelajaran online adalah bagian dari pembelajaran berbasis teknologi yang memanfaatkan sumber 
daya Internet, intranet, dan extranet. Lebih khusus lagi Rosenberg (2001: 28-29) mendefinisikan e-learning sebagai pemanfaatan teknologi Internet untuk mendistri-busikan materi pembelajaran, sehingga siswa dapat mengakses dari mana saja.

Mason dan Rennie (2009: 12) menyatakan biasanya definisi e-learning berbeda tergantung pada penekanannya, ada yang penekanannya fokus pada konten, ada yang fokus pada komunikasi, dan ada yang fokus pada teknologi. Munir (2009: 167) menyatakan bahwa persepsi dasar e-learning terbagi dua yaitu: (a) e-learning adalah pembelajaran yang memanfaatkan teknologi informasi dan komunikasi, terutama perangkat yang berupa elekronik; dan (b) e-learning adalah pembelajaran yang menggunakan fasilitas internet yang bersifat online sebagai instrumen utamanya. Naidu (2006: 1) mendefinisikan $e$ learning sebagai penggunaan teknologi informasi dan komunikasi dalam pengajaran dan pembelajaran.

Banyak sekali model pembelajaran berbasis web berkembang saat ini. Ada yang memanfaatkan media web sebagai suplemen atau tambahan saja, ada yang memanfaatkan media web sebagai pengganti sebagian pembelajaran tatap muka di kelas, dan ada pula yang memakai media web secara penuh untuk proses belajar mengajarnya. Menurut Kudwadi \& Suryadi (2010: 7-8) jika bobot pembelajaran tradisional lebih besar dari pembelajaran berbasis web disebut Web Enhanced Course, sedangkan jika berbasis web lebih besar disebut Web Centric Course, sedangkan jika seratus persen berbasis web disebut Web Course. Sedangkan Robin Mason \& Rennie (2009: 38) dari United Kingdom Open University menyatakan bahwa kebanyakan perkuliahan online yang ada sekarang bersifat "partially online" atau "fully online-learning course". Untuk partially online biasanya dikenal dengan blended learning.

Blended learning atau hybrid courses adalah pembelajaran yang memadukan antara komponen online dan komponen tatap muka (Garrison \& Vaughan, 2008:4). Kenyataannya, program belajar yang mengandung komponen online sekecil apa pun (misalnya: situs web pendukung, akses email ke instruktur, daftar bacaan online) kadangkadang disebut sebagai e-learning. Hal itu juga menggambarkan semua program belajar yang memadukan berbagai media pembelajaran atau berbagai kesempatan pembelajaran.

Bersin \& Associates (2003: 1) dalam papernya "Blended Learning: what works?" menyatakan bahwa setelah penelitian 2 tahun dan interviu dengan lebih 3 perusahaan maka mereka menyimpulkan: "Blended learning is replacing e-learning as the next big thing". Indikatornya yaitu blended learning memiliki dampak tertinggi dan biaya terendah. Blended learning juga menyelesaikan masalah kecepatan, skala, dan dampak.

Caraivan (2011:1) menambahkan e-learning mulai ditinggalkan dan orang-orang mulai beralih kepada blended learning. Beberapa sebabnya yaitu karena dengan pembelajaran $e$ learning mahasiswa: (a) tidak termotivasi secara maksimal; (b) tidak bertanggung jawab; (c) merasa terisolasi; dan (d) merasa tidak ada dukungan. Beberapa kelemahan ini mengakibatkan orang mulai mencari model pembelajaran alternatif yang dapat mengurangi dampak negatif dari e-learning ini.

Mason \& Rennie (2006: 17) menyatakan solusi blended yang sering digunakan adalah: 50/50 untuk model pembelajaran tatap muka dan pembelajaran online yang bisa menggabungkan kedua sisi. Bahkan 75 persen online dengan 25 persen tatap muka atau pertemuan residensial juga berhasil dalam mengatasi keterbatasan pembelajaran online sambil tetap memberi manfaat bagi fleksibilitasnya dan keseluruhan penghematan biaya.

Pendekatan blended dapat mendorong peserta untuk memanfaatkan sebaik-baiknya kontak face-to-face dalam mengembangkan pengetahuan. Lalu, persiapan dan tindaklanjutnya dapat dilakukan secara online. Program belajar yang total online tidak dianjurkan untuk kontak bagi yang tidak mungkin atau tidak masuk akal bagi para pebelajar untuk datang bersama-sama. Contohnya yaitu acara ber-level internasional, program belajar 
pelatihan internasional, atau proyek-proyek yang pembelajarannya tidak dapat meninggalkan tempat operasionalnya. Teknologi synchronous bisa menyediakan penggantinya secara parsial.

Artikel yang ditulis Singh (2003: 51-54) memberikan pandangan yang komprehensif tentang blended learning, dan mendiskusikan dimensi dan ingredient (metode penyampaian pembelajaran) dari program blended learning; dan juga memberikan model untuk menghasilkan campuran yang sesuai dengan memastikan bahwa masing-masing ingredient, baik secara individual maupun kolektif, menambah arti dalam pengalaman belajar. Blended learning harus digunakan sebagai pendekatan dalam suatu strategi untuk mendapatkan "the right content in the right format to the right people at the right time."

Banyak sekali model-model blended learning berkembang, diantaranya yaitu: supplemental, replacement, dan emporium (Caraivan, 2011: 4-5). Model pertama, supplemental yaitu model blended learning yang memakai struktur pembelajaran tradisional dan menggunakan sumber-sumber berbasis teknologi sebagai suplemen. Walaupun ada penggunaan teknologi, tetapi hal ini tidak merubah struktur pembelajaran. Mahasiswa belajar dan menerima materi pembelajarannya secara online, tetapi mereka tetap bertemu dengan dosen dalam pembelajaran tatap muka seperti pembelajaran tradisional. Model yang kedua, replacement yaitu model yang menggantikan beberapa pertemuan tatap muka di kelas dengan online, melalui aktivitas interaktif. Beberapa perbedaan pokok dalam model ini yaitu sumber-sumber online terintegrasi dalam pengalaman belajar dan juga adanya komunikasi secara online. Terdapat juga sumbersumber online untuk dipelajari dan pada pertemuan tatap muka dilakukan kegiatan yang bersifar interaktif dan kolaboratif. Pada model ketiga, emporium yaitu model yang menggantikan semua pertemuan tatap muka di kelas dengan portal pembelajaran. Portal ini menyediakan akses ke materi online, konsultasi online, dan dukungan online. Komunikasi seutuhnya tergantung kepada koneksi Internet.

Bagaimana mengembangakan suatu model Blended Learning and apa-apa saja yang harus dipertimbangkan dalam mengembangkan model ini? Artikel ini akan membahas mengenai langkah pengembangan model Blended Learning Interaktif (BLI) dengan prosedur pengembangan Borg and Gall.

\section{DISKUSI}

Model pengembangan yang dibahas dalam artikel ini yaitu model prosedural dari Borg \& Gall. Menurut Borg \& Gall (1983: 772) penelitian pengembangan yaitu:

"... a process used to develop and validate educational product...which consist of studying research finding pertinent to the product to be developed, developing the product based on these findings, field testing it in the setting where it will be used eventually, and revising it to correct the deficiencies found in the field-testing stage."

Dari definisi tersebut dipahami bahwa penelitian pengembangan adalah suatu proses yang digunakan untuk mengembangkan dan memvalidasi produk pendidikan. Proses yang dilakukan terdiri dari analisis hasil penelitian yang berkaitan dengan produk yang dikembangkan, mengembangkan produk berdasarkan hasil temuan, uji coba lapangan, dan revisi untuk memperbaiki kekurangan yang ditemukan dalam tahap uji coba lapangan.

Karakteristik khusus dari penelitian pengembangan ini yaitu (Gall, Gall, \& Borg, 2003: 569-572): (a) mengembangkan produk, seperti: buku teks, buku ajar, cara pengorganisasian pengajaran, alat evaluasi, model pembelajaran, dan sebagainya; (b) berjenjang dalam penilaian model/produk; (c) menjembatani kesenjangan yang terjadi antara education research dengan education practice; (d) bersifat kuantitatif dalam memvalidasi efektivitas, efisiensi, keberterimaan model/produk, dan bersifat kualitatif dalam penyusunan model/produk, validasi ahli, dan revisinya; (e) ada uji lapangan dan 
distribusi, uji lapangan dilakukan untuk memvalidasi prototype, dan distribusi sebagai suatu diseminasi prototype yang telah teruji (model/produk); (f) menekankan pada masalah khusus yang berhubungan dengan masalah-masalah praktis dalam pengajaran melalui applied research; dan (g) ada tahapan-tahapan evaluasi terhadap model/produk yang disusun.

Ada empat prinsip dasar yang melandasi penelitian dan pengembangan (Soenarto, 2013), yaitu: (a) commitment to quality improvement, bahwa dosen yang mempunyai tugas utama menyelenggarakan pembelajaran yang berkualitas harus mempunyai komitmen untuk mengadakan perbaikan dan peningkatan kualitas proses pembelajaran secara berkelanjutan; (b) integrated in work, bahwa pengembangan model, sistem, atau alat yang dikembangkan merupakan bagian integral dari proses pembelajaran; (c) scientific endeavor, bahwa dalam pengembangan model dan perangkat pembelajaran dilakukan melalui tahapan dan alur kaidah ilmiah; dan (d) consistence, adanya konsistensi sikap dan kepedulian dalam upaya memperbaiki dan meningkatkan kualitas kinerja. Hal ini sangat penting karena penelitian dan pengembangan harus dilakukan secara sungguh-sungguh, berkolaborasi dengan kolega dosen, melibatkan para pakar yang ahli dalam bidang yang terkait dengan model dan perangkat pembelajaran yang akan dihasilkan.

Ada sepuluh (10) langkah yang harus dilakukan jika menggunakan model Borg \& Gall untuk pengembangan suatu model/produk. Kesepuluh langkah dimaksud masing-masing dijelaskan sebagai berikut:

\section{a. Penelitian pendahuluan/prasurvei}

Tujuannya yaitu untuk mengumpulkan informasi mengenai model/produk yang dikembangkan dan mengidentifikasi permasalahan yang mungkin dijumpai dalam pengembangan model/produk. Langkah pertama ini meliputi: kajian pustaka, pengamatan model yang telah ada, identifikasi masalah-masalah yang ada dalam pengembangan model/produk, analisis kebutuhan, dan studi kelayakan.

\section{b. Perencanaan penelitian}

Perencaaan penelitian meliputi: (1) perumusan tujuan penelitian; (2) perkiraan dana, tenaga, dan waktu; (3) perumusan kualifikasi peneliti dan bentuk-bentuk partisipasinya dalam penelitian.

\section{c. Pengembangan model/produk awal}

Langkah ini meliputi: (1) penentuan disain produk yang akan dikembangkan (disain hipotetik); (2) penentuan sarana dan prasarana penelitian yang dibutuhkan selama proses penelitian dan pengembangan; (3) penentuan tahap-tahap pelaksanaan uji disain di lapangan; (4) penentuan deskripsi tugas pihak-pihak yang terlibat dalam penelitian.

\section{d. Uji ahli dan pelaksanaan uji coba lapangan awal}

Langkah ini merupakan uji model/produk menurut ahli terkait dan disertai dengan uji lapangan awal secara terbatas, meliputi: (1) uji lapangan awal terhadap desain model/produk; (2) bersifat terbatas, baik substansi desain maupun pihak-pihak yang terlibat; (3) uji lapangan awal dilakukan secara berulang-ulang sehingga diperoleh desain layak, baik substansi maupun metodologi.

\section{e. Revisi hasil uji lapangan awal/terbatas}

Langkah ini merupakan perbaikan model atau desain berdasarakan uji lapangan terbatas. Penyempurnaan produk awal dilakukan setelah dilakukan uji coba lapangan secara terbatas. Pada tahap penyempurnaan produk awal, lebih banyak dilakukan pendekatan kualitatif. Evaluasi yang dilakukan lebih pada evaluasi terhadap proses, sehingga perbaikan yang dilakukan bersifat perbaikan internal.

\section{f. Pelaksanaan uji lapangan utama}

Langkah ini merupakan uji model/produk secara lebih luas, meliputi: (1) uji efektivitas desain model/produk, biasanya menggunakan teknik eksperimen model pengulangan; (2) 
hasil uji lapangan diperoleh desain yang efektif, baik dari sisi substansi maupun metodologi.

\section{g. Revisi hasil uji lapangan utama}

Langkah ini merupakan perbaikan kedua setelah dilakukan uji lapangan yang lebih luas dari uji lapangan yang pertama. Penyempurnaan produk dari hasil uji lapangan lebih luas ini lebih memantapkan produk yang dikembangkan, karena pada tahap uji coba lapangan sebelumnya dilaksanakan dengan adanya kelompok kontrol. Desain yang digunakan adalah pre-test dan post-test. Selain perbaikan yang bersifat internal, penyempurnaan produk ini didasarkan pada evaluasi hasil sehingga pendekatan yang digunakan adalah pendekatan kuantitatif.

\section{h. Uji kelayakan/uji lapangan operasional}

Langkah ini dilakukan dengan skala besar. Pada tahap ini dilakukan uji efektivitas dan adaptabilitas desain model/produk yang melibatkan calon pemakai model/produk.

\section{i. Revisi final hasil uji kelayakan}

Langkah ini akan lebih menyempurnakan produk yang dikembangkan. Penyempurnaan produk akhir perlu untuk lebih akuratnya produk yang dikembangkan. Pada tahap ini sudah didapatkan suatu model/produk yang tingkat efektivitasnya dapat dipertanggungjawabkan. Hasil penyempurnaan akhir memiliki nilai "generalisasi" yang dapat diandalkan.

\section{j. Diseminasi dan implementasi produk akhir}

Pada tahapan ini dibuat laporan hasil dari R \& D melalui forum-forum ilmiah, ataupun melalui media massa. Distribusi produk dilakukan setelah melalui kontrol kualitas.

Beberapa penelitian pengembangan yang berhasil diperoleh menunjukkan bahwa 10 langkah pengembangan Borg \& Gall bisa tidak dilakukan semuanya, tapi dapat dimodifikasi ke dalam beberapa langkah dan tahapan sesuai dengan kebutuhan pengembangan yang dilakukan oleh peneliti, misalnya Emzir (2008: 271) mengelompokkan menjadi enam (6) langkah; dan Pusat Penelitian Kebijakan dan Inovasi (Puslitjaknov, 2008: 11) menggunakan kesepuluh langkah dibagi menjadi lima (5) tahapan.

Sebagai contoh, untuk mengembangkan model Blended Learning Interaktif ini, prosedur Borg \& Gall yang digunakan hanya sampai dengan langkah ke 7, dan dibagi ke dalam empat (4) tahapan penelitian seperti terlihat pada Tabel 1.

Tabel 1. Langkah-Langkah dan Prosedur Penelitian

\begin{tabular}{|l|l|}
\hline \multicolumn{1}{|c|}{ langkah Borg \& Gall } & \multicolumn{1}{|c|}{$\begin{array}{l}\text { Empat (4) tahap penelitian pengembangan } \\
\text { Model Blended Learning Interaktif (BLI) }\end{array}$} \\
\hline $\begin{array}{l}\text { 1. Penelitian awal dan pengumpulan } \\
\text { informasi }\end{array}$ & $\begin{array}{l}\text { I. Identifikasi masalah dan analisis } \\
\text { kebutuhan }\end{array}$ \\
\hline $\begin{array}{l}\text { 2. Perencanaan } \\
\text { 3. Pembuatan produk awal, dan validasi } \\
\text { ahli }\end{array}$ & $\begin{array}{l}\text { II. Perencanaan, pembuatan Model BLI awal, } \\
\text { dan Validasi ahli }\end{array}$ \\
\hline $\begin{array}{l}\text { 4. Uji lapangan awal } \\
\text { 5. Revisi produk awal }\end{array}$ & III.Uji lapangan I, dan revisi awal \\
\hline $\begin{array}{l}\text { 6. Uji lapangan utama } \\
\text { 7. Revisi produk operasional }\end{array}$ & IV. Uji lapangan II, dan revisi akhir \\
\hline
\end{tabular}

Penjelasan lebih lanjut untuk setiap tahap pengembangan yang diadopsi dari langkahlangkah pengembangan Borg \& Gall adalah sebagai berikut:

Tahap I: Identifikasi Masalah dan Analisis Kebutuhan 
Tahap ini mencakup kajian literatur, penyusunan kuesioner analisis kebutuhan, pengumpulan data di Program Studi Teknik Elektro dan Pusat Komputer Universitas yang bertujuan untuk mengumpulkan informasi mengenai masalah-masalah yang dihadapi dan kesiapan baik program studi maupun Universitas dalam melaksanakan blended learning.

Masalah-masalah yang dihadapi dan kesiapan melaksanakan blended learning ini meliputi ketersediaan perangkat keras dan perangkat lunak, kesiapan dosen mengembangkan blended learning untuk mata kuliah yang mereka ampu, serta bagaimana kesiapan dan harapan maha-siswa untuk mengikuti pembelajaran dengan blended learning. Selain itu juga diteliti model blended learning yang sudah dikembangkan, dan mengidentifikasi permasalahan yang mungkin dijumpai dalam pengembangan model blended learning. Tahap ini menghasilkan dasar teoretis pengembangan model, kesediaan dan kelayakan menggunakan e-learning sebagai pengganti sebagian kuliah tatap muka, keadaan objektif pembelajaran e-learning, dan masalah-masalah yang perlu diatasi dalam mengembangkan blended learning.

\section{Tahap II: Perencanaan, Pembuatan Model BLI Awal, dan Validasi Ahli}

a. Perencanaan dan Pembuatan Model BLI Awal

Informasi yang sudah diperoleh pada tahap identifikasi masalah dan analisis kebutuhan, digunakan untuk merencanakan dan mengembangkan Model Blended Learning Interaktif awal, yang disebut dengan Model Blended Learning Interaktif (BLI) konseptual. Kegiatan pada tahap ini meliputi: (a) desain awal Model BLI; (b) desain perangkat pembelajaran Model BLI yang meliputi: silabus, rancangan pembelajaran, dan materi pembelajaran, dan (c) desain kuesioner penelitian, yang meliputi kuesioner penilaian Model BLI baik oleh para ahli, dosen, dan mahasiswa; serta kuesioner hasil belajar mesin listrik. Jadi tahap ini menghasilkan Model BLI konseptual; draft silabus, draft rancangan pembelajaran, draft materi pembelajaran dalam bentuk naskah dan digital untuk web; serta draft kuesioner penelitian yang meliputi: draft format penilaian untuk para ahli dan dosen; draft kuesioner persepsi mahasiswa terhadap pembelajaran Model BLI, serta draft tes hasil belajar mesin listrik dengan pokok bahasan transformator.

b. Validasi Ahli

Validasi oleh ahli meliputi: (1) validasi Model BLI konseptual melalui focus group dicussion (FGD); (2) validasi perangkat model yan meliputi: draft silabus, draft rancangan pembelajaran, dan draft materi pembelajaran melalui penilaian dosen pembina mata kuliah Mesin Listrik Universitas Negeri Padang (UNP); dan (3) validasi draft kuesioner penelitian yang meliputi: tes hasil belajar dan kuesioner persepsi mahasiswa terhadap Model BLI melalui penilaian oleh dosen pembina mata kuliah Mesin Listrik UNP dan dosen Pascasarjana Universitas Negeri Yogyakarta (UNY).

Ahli yang dilibatkan untuk validasi ahli ini meliputi ahli bidang studi mesin-mesin listrik, ahli komputer, ahli TIK, ahli pembelajaran, dan ahli evaluasi/ asesmen. Para ahli dipilih secara purposive berdasarkan kompetensi dan pengalamannya dalam bidang yang terkait dengan model yang dikem-bangkan.

\section{Tahap III: Uji Lapangan I, dan Revisi Awal}

a. Uji Lapangan I

Uji lapangan I meliputi uji efektivitas Model BLI dan uji validitas dan raliabilitas empiris kuesioner penelitian. Uji lapangan I ini dilakukan selama delapan sesi untuk materi transformator pada satu rombongan belajar. Dari delapan sesi, tiga sesi $(37,5 \%)$ yaitu sesi pertama, ke lima, dan sesi kedelapan dilakukan secara tatap muka di dalam kelas, sedangkan lima sesi $(62,5 \%)$ lainnya dilaksanakan dengan e-learning berbasis web. 
Pertemuan awal digunakan untuk menjelaskan segala sesuatu yang berhubungan dengan pembelajaran dengan Model BLI dan melaksanakan pre-test. Sesi kelima digunakan untuk diskusi kelas tentang materi yang dianggap belum dikuasai. Sesi kedelapan digunakan untuk post-test dan mengisi kuesioner persepsi mahasiswa tentang pelaksanaan pembelajaran dengan menggunakan Model BLI.

b. Revisi Awal

Revisi awal didasarkan pada informasi yang diperoleh melalui validasi ahli dan uji lapangan I. Revisi awal ini menghasilkan: (1) Model BLI setelah FGD yang sudah valid; (2) Perangkat pembelajaran (silabus, rancangan pembelajaran, dan materi perkuliahan) yang sudah valid; (3) Kuesioner penelitian (tes hasil belajar dan kuesioner persepsi mahasiswa terhadap Model BLI) yang sudah memiliki validitas isi untuk tes hasil belajar, dan validitas konstruk untuk kuesioner persepsi mahasiswa terhadap Model BLI. Selain itu, untuk kedua kuesioner ini juga sudah didapatkan validitas dan reliabilitas empirisnya.

\section{Tahap IV: Uji Lapangan II, dan Revisi Akhir}

Pada tahap ini dilakukan uji Model BLI hipotesis yang lebih luas. Hasil uji lapangan II dijadikan sebagai hasil Model BLI final, setelah dilakukan revisi akhir. Pada uji lapangan II diuji efektivitas dan kepraktisan Model BLI hipotetis. Hasil uji lapangan ini selanjutnya digunakan untuk merevisi Model BLI dan perangkat pembelajaran Model BLI secara menyeluruh.

Prosedur penelitian dengan keempat tahapan pengembangan prosedur penelitian dengan keempat tahapan pengembangan Model BLI dapat digambarkan melalui Gambar 1.

\section{KESIMPULAN}

a. penelitian pengembangan adalah suatu proses yang digunakan untuk mengembangkan dan memvalidasi produk pendidikan.

b. Pada dasarnya terdapat sepuluh langkah pengembangan Borg \& Gall, tetapi kesepuluh langkah ini bisa tidak dilakukan semuanya, tapi dapat dimodifikasi ke dalam beberapa langkah dan tahapan sesuai dengan kebutuhan pengembangan yang dilakukan.

\section{REFERENSI}

ANTA. (2003). Definition of key terms used in e-learning (version 1.00). Diakses Oktober 20, 2012, dari http://www.flexiblelearning.net.au/guides /keyterms. pdf.

Bersin, \& Associates. (2003). Blended learning: what works?. Diakses pada Tanggal 20 Oktober 2012, dari education-2020.wikispaces.com/file/view/blended bersin.doc.

Borg, W. R., \& Gall, M. D. (1983). Educational research: an introduction. London: Longman, Inc.

Caraivan, L. (2011). Blended learning: from concept to implementation. Euromentor Journal, II(4).

Emzir. (2008). Metodologi penelitian pendidikan: kuantitatif dan kualitatif. Jakarta: PT. Rajagrafindo Persada.

Gall, M. D., Gall, J. P., \& Borg, W. R. (2003). Educational research: an introduction (7 ed.). New York: Pearson Education Inc.

Garrison, D. R., \& Vaughan, N. D. (2008). Blended learning in higher education: framework, principles, and guidelines. San Fransisco: John Willey \& Sons.

Gilbert, \& Jones, M. G. (2001). E-learning is e-normous. Electric Perspectives, 26(3), 6682.

Kudwadi, B., \& Suryadi, D. (2010). Pengembangan kerangka elearning dalam pembelajaran teknologi dan kejuruan. Artikel Penelitian. 
Mason, R., \& Rennie, F. (2009). Elearning: panduan lengkap memahami dunia digital dan internet. Diterjemahkan dari: Elearning oleh Taylor Francis. London-New York. Surabaya: Penerbit Baca!

Munir. (2009). Pembelajaran jarak jauh berbasis teknologi informasi dan komunikasi. Bandung: Alfabeta.

Naidu, S. (2006). Elearning: a guide book of principles, procedures, and practice. New Delhi: Creative Workshop.

Puslitjaknov. (2008). Metode penelitian pengembangan. Pusat Penelitian Kebijakan dan Inovasi Pendidikan, Badan Penelitian dan Pengembangan, Departemen Pendidikan Nasional.

Rosenberg, M. J. (2001). E-learning: strategies for delivering knowledge in the digital age. New York: McGraw-Hill.

Singh, H. (2003). Building effective blended learning program. Educational Technology, 43(6), 51-54.

Soenarto. (2013). Konsep dasar metode penelitian dan pengembangan (research and development). Dalam Metodologi Penelitian Pendidikan. Yogyakarta: UNY Press.

Sohn, B. (2005). E-learning and primary and secondary education in Korea. KERIS Korea Education \& Research Information Service, 2(3), 6-9.

Surya, M. (2006). Potensi teknologi informasi dan komunikasi dalam peningkatan mutu pembelajaran di kelas. Makalah dalam Seminar Pemanfaatan TIK untuk Pendidikan Jarak Jauh dalam Rangka Peningkatan Mutu Pembelajaran. Diselenggarakan oleh Pustekkom Depdiknas, Tanggal 12 Desember 2006 di Jakarta. 


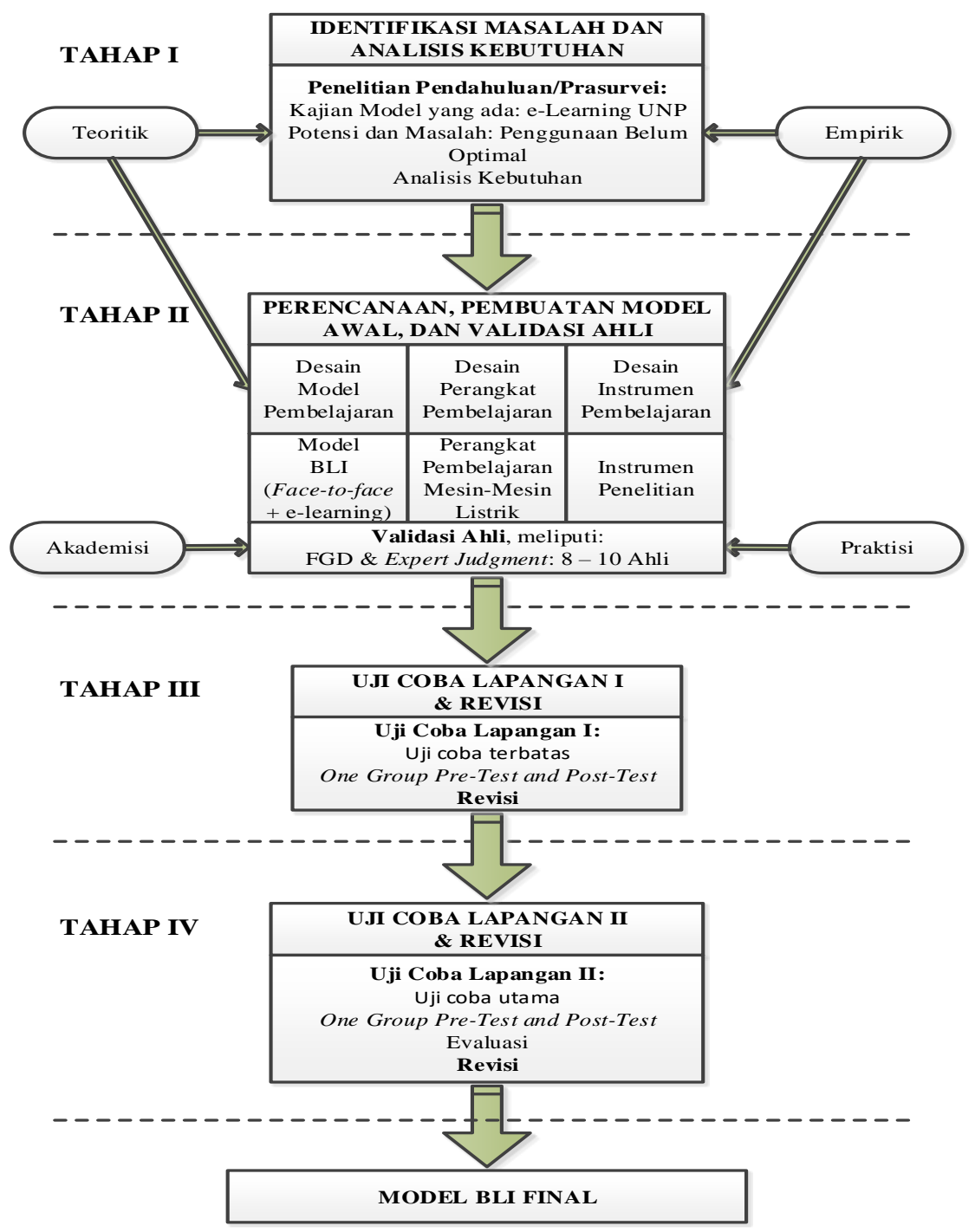

Gambar 1. Prosedur Penelitian Pengembangan Model BLI 